\title{
ISOLATION OF HYALURONATEPROTEIN FROM HUMAN SYNOVIAL FLUID*
}

\author{
By JOHN SANDSON $\dagger$ AND DAVID HAMERMAN, $\ddagger$ WITH THE TECHNICAL ASSISTANCE OF \\ HILDA SCHUSTER AND LAWRENCE A. WILLIAM
}

\author{
(From the Department of Medicine, Albert Einstein College of Medicine, and the Bronx \\ Municipal Hospital Center, New York, N. Y.)
}

(Submitted for publication April 16, 1962 ; accepted June 7, 1962)

The high molecular weight components of synovial fluid are hyaluronate and proteins. Hyaluronate is synthesized by cells of the synovial membrane, and its concentration in normal human synovial fluid is about $3 \mathrm{mg}$ per $\mathrm{g}$ (1). Proteins in synovial fluid appear to be identical with those in serum (2). The protein concentration in normal synovial fluid is about $20 \mathrm{mg}$ per $\mathrm{g}$. A problem of considerable interest is whether hyaluronate in synovial fluid is free or exists as a compound with protein. To answer this question, electrophoresis or ultrafiltration have been used in attempts to separate hyaluronate from the proteins of synovial fluid. Some samples of hyaluronate, isolated from human or bovine synovial fluid by electrodialysis at $\mathrm{pH} 7.2$, and treated with Celite to remove protein impurities, had a molar ratio of nitrogen to hexosamine of 1.00 and so were apparently protein-free $(3,4)$. Hyaluronate's enormous molecular weight $\left(1 \times 10^{6}\right.$ or more $)$ and even greater molecular volume compared to proteins of synovial fluid account for the retention of hyaluronate on special filters that allow proteins to pass through. In contrast to the products obtained by electrodialysis, hyaluronate isolated from bovine synovial fluid by 19 consecutive ultrafiltrations on sintered glass contained 25 per cent protein (5). It was thought that this protein was firmly bound to hyaluronate, and necessary for the anomalous viscosity of hyaluronate solutions. Later it was shown that over 65 per cent of the protein in this product could be removed by trypsin digestion

* Supported by Training Grant 2A-5082, National Institute of Arthritis and Metabolic Diseases, and by grants from the N. Y. State Chapter, Arthritis and Rheumatism Foundation. Part of this work was presented before the American Rheumatism Association, June 1961.

† Investigator, Health Research Council of the City of New York (contract no. I-157).

$\ddagger$ Markle Scholar in Medical Science. without altering hyaluronate's anomalous viscosity (6).

The state of the hyaluronate in native synovial fluid needs to be clarified. Some properties of the hyaluronate might depend on the presence of a firmly bound protein moiety, as, for example, the physical properties of chondromucoprotein isolated from bovine nasal cartilage are due to the combination of chondroitin sulfate and a noncollagenous protein. This paper describes the isolation of hyaluronate from normal human synovial fluid by either ultrafiltration or zone electrophoresis. The final products were treated with adsorbents to remove protein impurities. Isolated by either method, hyaluronate contained about 2 per cent protein. This quantity of protein could not be detected regularly by molar ratios of nitrogen to glucosamine, and special methods were required to confirm its presence. This protein was also shown to be firmly combined with the hyaluronate. Objections have been raised to the use of terms such as "mucoprotein" or polysaccharide-protein "complex," and it has been suggested that "proteinpolysaccharide" be used (7). In this paper the compound isolated from synovial fluid will be termed "hyaluronateprotein" (HP).

\section{EXPERIMENTAL METHODS}

1. Synovial fluid was obtained with sterile techniques from subjects who died of acute injuries and who were apparently free of joint disease. Some fluids were obtained from living subjects with normal joints. Fluids were stored at $5^{\circ} \mathrm{C}$ and used within 1 week. The protein content of these fluids was less than $25 \mathrm{mg}$ per $\mathrm{g}$.

2. Isolation of HP by ultrafiltration. A combination of ultrafiltration, adsorption, and ultracentrifugation was used to isolate HP from pooled synovial fluids. Progressive removal of proteins was most simply followed by determining the ratio $\mathrm{mg}$ protein $/ \mathrm{mg}$ hyaluronate (hexuronic acid $\times 2.5=$ hyaluronate). Adsorption was carried out by passing synovial fluid through a column of IRC-50 and hydroxylapatite. Ultrafiltration of fluids 
on sintered glass was a prolonged process, and much more rapid filtration was achieved by using special cellulose filters and glass filtration flasks. ${ }^{1}$ Hyaluronate was found to pass through filters ranging in pore diameter from $5 \mu$ to $0.22 \mu$, but was retained completely on $0.1 \mu$ filters. Synovial fluid proteins filtered slowly through the viscous gel of hyaluronate retained on the $0.1 \mu$ filter, and were not removed completely by a single ultrafiltration. Accordingly, the hyaluronate was dissolved and ultrafiltered at least 4 times. Ultracentrifugation of the ultrafilter residue was carried out to remove traces of insoluble protein. In our experience, the most suitable procedure for the isolation of hyaluronate from large quantities of human synovial fluid is as follows.

Samples of synovial fluid were pooled to provide about $20 \mathrm{~g}$, and this was diluted 1:10 with a $\mathrm{pH} 7.2$ phosphate$\mathrm{NaCl}$ buffer $(0.04 \mathrm{M}$ phosphate, $0.10 \mathrm{M} \mathrm{NaCl})$. The diluted fluid was dialyzed for 24 hours at $5^{\circ} \mathrm{C}$ against 2 $500-\mathrm{ml}$ changes of the buffer. The column for adsorption was prepared as follows: $50-\mathrm{ml}$ equal volumes of packed hydroxylapatite (8) and IRC-50 resin were equilibrated with the buffer, mixed, and added to a glass tube $2.5 \times 50$ $\mathrm{cm}$ stoppered with a plug of cotton wool. The mixture settled without pressure, forming a column $2.5 \times 16 \mathrm{~cm}$ that was kept at $5^{\circ} \mathrm{C}$. The dialyzed, diluted synovial fluid was added to the column and eluted with the buffer. The rate of flow through the column was kept constant by maintaining the level of buffer $20 \mathrm{~cm}$ above the column of adsorbents. The large volume of eluate from the column, about $500 \mathrm{ml}$, was divided among 6 filtration flasks containing Millipore filters of $0.1 \mu$ pore diameter. These flasks were evacuated to about $1 \mathrm{~mm} \mathrm{Hg}$ and kept at $5^{\circ} \mathrm{C}$. When ultrafiltration was complete, at about 36 to 48 hours, the material retained on the filter was washed by adding $10 \mathrm{ml}$ of the buffer and the flasks were re-evacuated. When this added buffer was filtered completely, the filter was placed in a $100-\mathrm{ml}$ glass beaker containing about $15 \mathrm{ml}$ of phosphate- $\mathrm{NaCl}$ buffer. The viscous mass of hyaluronate was scraped off the filter with a plastic rod, and the beaker was shaken at $5^{\circ} \mathrm{C}$ for 24 hours to dissolve the hyaluronate. The viscous fluid was then ultracentrifuged (Spinco) 30 minutes at $105,000 \times \mathrm{G}$ to remove insoluble material. The sediment was washed with buffer and ultracentrifuged again. The supernatant fluids were combined and ultrafiltered. The process of ultrafiltration and ultracentrifugation was carried out 3 or 4 times. Part of these final products was dialyzed against KAc $(0.15 \mathrm{M})$ and the $\mathrm{HP}$ precipitated with 3 volumes of ethanol at $5^{\circ} \mathrm{C}$, washed with ether, and dried over $\mathrm{P}_{2} \mathrm{O}_{5}$ in a vacuum.

3. Isolation of HP by zone electrophoresis. HP was isolated from small quantities (1 $\mathrm{g}$ ) of normal human synovial fluid by zone electrophoresis at $\mathrm{pH} 5.4$ by methods previously described (9). Protein impurities were removed by adsorption with IRC-50 resin and hydroxylapatite.

4. a) Labeling with $I^{131}(10)$. To a test tube $13 \times 100$ $\mathrm{mm}$, the following were added in order : $0.05 \mathrm{ml} \mathrm{KI}(0.01$

1 Millipore Corp., Bedford, Mass.
$\mathrm{M}), 10$ to $100 \mu \mathrm{c} \mathrm{I}{ }^{131}, 0.2 \mathrm{ml} \mathrm{HCl}(2.5 \mathrm{~N}), 0.05 \mathrm{ml}$ $\mathrm{Na}_{2} \mathrm{NO}_{2}(1 \mathrm{M})$, and $0.5 \mathrm{ml} \mathrm{NaOH}(1 \mathrm{~N})$. The con-

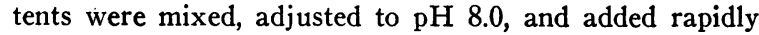
with constant stirring to a solution of $\mathrm{HP}$, usually 1 to 2 $\mathrm{g}$ with $1.25 \mathrm{mg} \mathrm{HP}$ per $\mathrm{g}$, which had been previously dialyzed 8 hours against $2250-\mathrm{ml}$ changes in a $\mathrm{pH} 8.1$ borate buffer ( 1 part $0.16 \mathrm{M} \mathrm{NaOH}$ added to 5 parts $0.16 \mathrm{M} \mathrm{NaCl}$ and $0.2 \mathrm{M}$ boric acid). The mixture was incubated at room temperature for 10 minutes. The free iodine was removed by dialysis at $5^{\circ} \mathrm{C}$ for 48 hours against $41000-\mathrm{ml}$ changes of a $\mathrm{pH} 7.2$ buffer $(.15 \mathrm{M}$ $\mathrm{NaCl}, 0.01 \mathrm{M}$ phosphate).

b) Labeling with $\mathrm{Cr}^{51} \mathrm{Cl} . \mathrm{Cr}^{51} \mathrm{Cl}, 50 \mu \mathrm{c}$, was added to hyaluronate that had been dialyzed in the $.04 \mathrm{M}$ phosphate- $\mathrm{NaCl}$ buffer. The solution was mixed and incubated at room temperature for 1 hour. Free $\mathrm{Cr}^{51}$ was removed by dialysis at $5^{\circ} \mathrm{C}$ in the buffer.

5. Zone electrophoresis of labeled products. Polyvinyl chloride (Geon resin 427) ${ }^{2}$ was washed for 2 days with $\mathrm{NaCl}(0.15 \mathrm{M})$ and for 1 day in the buffer used for electrophoresis. The slurry was poured into a $21 \times 13 \times 0.5$ $\mathrm{cm}$ plastic mold that was subdivided longitudinally into five compartments, each $21 \times 2 \times .05 \mathrm{~cm}$, by glass rods wrapped in rubber tubing. Double-thickness Whatman no. 1 filter paper was used as wicks. The $0.5 \mathrm{ml}$ samples were added to a small $.02 \times 1 \times .05-\mathrm{cm}$ slit $4 \mathrm{~cm}$ from the cathodal end of each compartment. Five samples could be run simultaneously. Electrophoresis was performed at a voltage gradient of 15.5 volts per $\mathrm{cm}$ at $5^{\circ} \mathrm{C}$ for about 6 hours. After electrophoresis, the block was blotted dry, each compartment was cut into $1-\mathrm{cm}$ segments, and each segment was placed in a test tube $13 \times 100$ $\mathrm{mm}$. The $\mathrm{I}^{131}$ in each segment was determined by counting in a deep well scintillation counter. To each tube, 1 $\mathrm{ml}$ of the $.04 \mathrm{M}$ phosphate- $\mathrm{NaCl}$ buffer was added. The contents were mixed with a glass rod, and after centrifugation at $2500 \mathrm{rpm}$ for 10 minutes, the supernatant fluid was analyzed for hexuronic acid.

6. Chromatography. Ascending methods were carried out in stainless steel chambers ${ }^{3} 23 \mathrm{~cm}$ long, $9 \mathrm{~cm}$ wide, and $23 \mathrm{~cm}$ high with Whatman no. 1 paper $20 \mathrm{~cm}$ square.

Amino acids. $\mathrm{HP}$ was hydrolyzed in $6 \mathrm{~N} \mathrm{HCl}$ in a sealed tube for 17 hours at $105^{\circ} \mathrm{C}$ and the hydrolysate evaporated to dryness in a vacuum over $\mathrm{NaOH}$. The residue was dissolved in water, filtered through glass wool, evaporated to dryness, and dissolved in distilled water. Two ascents were made in butanol-acetic acidwater (12:3:5) (11) and a single ascent in a second dimension with a phenol solvent (12). Amino acids were detected with 0.25 per cent weight per volume of 1,2,3indantrione hydrate (Ninhydrin) in acetone.

Neutral sugars and mucleotides. Hydrolysis was carried out in $0.5 \mathrm{~N} \mathrm{HCl}$ in sealed tubes for 16 hours at $94^{\circ} \mathrm{C}$ and the hydrolysate evaporated to dryness. One or two ascents were made in isopropanol-water $(80: 20)$ (11). Nucleotides were detected by ultraviolet light

2 B. F. Goodrich Chemical Co.

3 A. H. Thomas, Phila., Pa. 
with a $2570 \AA$ lamp. 4 Amino and neutral sugars were located by an aniline reagent (12), and $\mathrm{N}$-acetylamino sugars by the method of Salton (13). The isopropanol solvent proved very useful; it did not diminish ultraviolet absorption of nucleotides as did solvents containing butanol, and it separated galactosamine and glucosamine.

7. Viscosity. All samples were first dialyzed in the $.04 \mathrm{M}$ phosphate- $\mathrm{NaCl}$ buffer. Samples were filtered through $5 \mu$ Millipore filters to remove threads or particles. To measure relative viscosity, an Ostwald viscometer (2-ml capacity) was used with a flow time for the buffer of 180 seconds in a constant temperature bath at $25^{\circ} \mathrm{C} \pm 0.1^{\circ} \mathrm{C}$. Anomalous viscosity was determined by a modification of the method of Levine and Kling (14) and the results were plotted according to methods of Barnett (15).

8. Ultracentrifugation. Analysis of $\mathrm{HP}(1.0 \mathrm{mg}$ per $\mathrm{g}$ in $.04 \mathrm{M}$ phosphate- $\mathrm{NaCl}$ buffer, $\mathrm{pH} 7.2$ ) was performed in a Spinco Model $E$ analytical ultracentrifuge at 59,780 $\mathrm{rpm}$ at $25^{\circ} \mathrm{C}$. A $4^{\circ}$ single sector cell with a $12-\mathrm{mm}$ aluminum centerpiece was used.

9. Digestion with bacterial hyaluronidases. There are several reasons for using bacterial rather than testicular hyaluronidases. 1) The bacterial enzymes used digest hyaluronate but not chondroitin sulfate. 2) The product of digestion is a $\Delta-4,5$ unsaturated disaccharide (16) that is completely dialyzable. 3) Digestion is carried out at $\mathrm{pH} 6$ to 7. On the other hand, digestion with testicular hyaluronidase must be carried out at $\mathrm{pH} 5$ or lower to produce 100 per cent dialyzable fragments (1). A1though tetrasaccharides are the main product, oligosaccharides are also produced that may dialyze with more difficulty.

Exhaustive digestion of HP with bacterial hyaluronidases was carried out as follows. A solution of HP (about $5 \mathrm{mg} \mathrm{HP}$ per $\mathrm{g}$ ) previously dialyzed in a $\mathrm{NaCl}$ acetate buffer at $\mathrm{pH} 6.2$ was incubated with $1 \mathrm{mg}$ of pneumococcal hyaluronidase 5 (100 turbidity reducing units [TRU] per $\mathrm{mg}$ ) for 16 hours at $37^{\circ} \mathrm{C}$. Then 1 $\mathrm{mg}$ of streptococcal hyaluronidase 6 (15 to 50 TRU per $\mathrm{mg}$ ) was added and incubation carried out an additional 3 to 4 hours. More prolonged incubation was avoided because a thread-like precipitate formed; the explanation of this is not known. The digested product was dialyzed at $5^{\circ} \mathrm{C}$ in $500 \mathrm{ml}$ of the $\mathrm{NaCl}$-acetate buffer at $\mathrm{pH} 6.2$, changed twice daily for 2 days. The hyaluronate fragments dialyzed completely; paper chromatography of a sample of the nondialyzable residue revealed no spots detectable with ultraviolet light or with aniline that would indicate the presence of the unsaturated disaccharide. Part of the nondialyzable residue was dialyzed in a $\mathrm{NaCl}$ acetate buffer at $\mathrm{pH} 6.8$ prior to further digestion with a liver enzyme ${ }^{5}$ containing $\beta$-glucuronidase and $\beta$-glucosaminidase.

10. Reaction with hydrazine (17). To $20 \mathrm{~g}$ of a solution of HP (1.5 mg HP per $\mathrm{g}$ ) was added $20 \mathrm{ml}$ of hy-

${ }^{4}$ G. Gates Co., Long Island, N. Y.

"Kindly provided by Dr. K. Meyer.

${ }^{6}$ Kindly provided by Wyeth Co., Phila., Pa. drazine $(2 \mathrm{M})$ adjusted to $\mathrm{pH} 8.6$ with glacial acetic acid. The mixture was incubated in a water bath at $40^{\circ} \mathrm{C}$ for 5 hours. Then $4 \mathrm{~N} \mathrm{HCl}$ was added to bring the mixture to $\mathrm{pH} 5$, and this solution was dialyzed at $5^{\circ} \mathrm{C}$ for 72 hours in $500 \mathrm{ml}$ distilled water changed twice daily. The dialyzed solution was concentrated to about $3 \mathrm{ml}$ and tested for free hydrazine and bound hydrazide, as follows.

a) Free hydrazine gives an immediate, intense color with Ehrlich's reagent $(2 \mathrm{~g} p$-dimethylaminobenzaldehyde, $100 \mathrm{ml}$ absolute ethanol, $30 \mathrm{ml}$ concentrated $\mathrm{HCl}$ ). To $1 \mathrm{~g}$ of the solution of the product in a $15 \times 150 \mathrm{~mm} \mathrm{Py-}$ rex tube $4 \mathrm{ml}$ of Ehrlich's reagent was added, and the absorbance was read at once at $450 \mathrm{~m} \mu$ in a Coleman, Jr. spectrophotometer. Run simultaneously were a reagent blank of $1 \mathrm{ml}$ distilled water, a solution of HP not treated with hydrazine, and a standard, glutamyl hydrazide (0.02 $\mu$ mole per $\mathrm{ml})$. The absorption of hydrazinetreated HP was less than .09 if free hydrazine had been removed completely by dialysis.

b) Bound hydrazide. Each tube was covered with a glass marble and heated in a water bath at $80^{\circ} \mathrm{C}$ for 30 minutes. Bound hydrazides were hydrolyzed by this procedure, and the hydrazine liberated reacted with Ehrlich's reagent. The tubes were cooled, and the absorbance at $450 \mathrm{~m} \mu$ was determined.

HP labeled with $\mathrm{I}^{131}$ was also treated with hydrazine, and zone electrophoresis was carried out at $\mathrm{pH} 4.5$ in an acetate buffer $(0.2 \mathrm{M})$. For controls, untreated $\mathrm{I}^{131}$-labeled HP and $\mathrm{I}^{131}$-labeled $\mathrm{HP}$ with added barbital buffer $(0.1 \mathrm{M})$ at $\mathrm{pH} 8.6$ were used.

11. Analysis. The methods for glucosamine and nitrogen have been described elsewhere (1). Protein was determined by a modified Folin method (18) with a $\gamma$-globulin solution as a standard. The nitrogen content of the protein standard was determined by a micro-Kjeldahl method. The hexuronic acid method of Dische (19) was used with modifications (20). The carbazole was twice recrystallized from alcohol and sublimed before use; after it was added, the tubes were allowed to stand for 2 hours and 45 minutes and the absorbance was determined in a Beckman DU spectrophotometer at $530 \mathrm{~m} \mu$. Ash was determined as $\mathrm{K}_{2} \mathrm{SO}_{4}$ after digestion with $\mathrm{H}_{2} \mathrm{SO}_{4}$, moisture by drying to constant weight at $105^{\circ} \mathrm{C} .^{7}$

\section{RESULTS}

1. Isolation of $H P$ by ultrafiltration. Data on the isolation of HP from pooled normal human synovial fluids are shown in Table I. The recovery of HP at each step is better than 90 per cent. The total yield of HP is about 75 per cent owing to some losses and to removal of samples at each step for analysis. After adsorption and two ultrafiltrations, little or no protein was removed by additional ultrafiltrations of HP.

‘ Schwarzkopf Lab., Woodside, N. Y. 
TABLE I

Data on the recovery of HP isolated from pooled normal human synovial fuids $(22 \mathrm{~g}$ )

\begin{tabular}{|c|c|c|c|c|c|c|}
\hline & \multicolumn{2}{|c|}{ Added } & \multicolumn{3}{|c|}{ Recovered } & \multirow{2}{*}{$\begin{array}{c}\text { Ratio } \\
\text { mg protein } \\
\text { mg hyal. }\end{array}$} \\
\hline & Hexur. acid & Protein & Hexuronic & Acid & Protein & \\
\hline Adsorption on & $m g$ & $m g$ & $m g$ & $\%$ & $m g$ & \\
\hline column (IRC, hydroxylap.) & 25.3 & 482 & 22.7 & 90 & 306 & 5.39 \\
\hline Ultrafiltration *1 & 22.6 & 30.3 & 22.9 & 100 & 2.15 & .037 \\
\hline Ultrafiltration 2 & 22.7 & 2.13 & 20.8 & 92 & 1.13 & .022 \\
\hline Ultrafiltration 3 & 20.7 & 1.08 & 19.6 & 95 & 1.04 & .021 \\
\hline
\end{tabular}

* Ultracentrifugation after each ultrafiltration.

The order in which these purification procedures should be used, and the number of times to use them, were studied. Table II shows that the molar ratios of nitrogen to glucosamine of the final products were similar whether 3 or 4 ultrafiltrations were followed by adsorption, or whether adsorption preceded ultrafiltration.

2. Iodination of $H P$ with $I^{131}$. A method was needed to show the firm combination of all the protein and hyaluronate in the final product. One way to show this is moving boundary electrophoresis, but the protein content of $\mathrm{HP}$ was too low to permit detection by optical methods. It was necessary to label the protein with $\mathrm{I}^{131}$. Then, by zone electrophoresis at $\mathrm{pH} 7.4$ or 8.6 , it

TABLE II

Progressive purification of HP: results of the order and frequency of the procedures used

\begin{tabular}{|c|c|c|c|}
\hline Product & Order of procedure* & $\begin{array}{c}\text { Ratio } \\
\text { mg protein/ } \\
\text { mg hyal. }\end{array}$ & $\begin{array}{l}\text { Molar } \\
\text { ratio } \\
N / \text { glu- } \\
\text { cosamine }\end{array}$ \\
\hline 1 & $\begin{array}{l}\text { 1. Ultrafilt. } \times 3 \\
\text { 2. Adsorpt. } \times 1 \\
\text { 3. Ultrafilt. } \times 1\end{array}$ & $\begin{array}{l}.055 \\
.016\end{array}$ & 1.15 \\
\hline $2 a$ & $\begin{array}{l}\text { 1. Ultrafilt. } \times 2 \\
\text { 2. Adsorpt. } \times 1 \\
\text { 3. Ultrafilt. } \times 1 \\
\text { 4. Adsorpt. } \times 1\end{array}$ & $\begin{array}{l}.080 \\
.048 \\
.012 \\
.012\end{array}$ & 1.16 \\
\hline $2 b$ & $\begin{array}{l}\text { 1. Zone electroph. pH } 5.4 \\
\text { 2. Adsorpt. } \times 1\end{array}$ & $\begin{array}{l}.055 \\
.017\end{array}$ & \\
\hline 3 & $\begin{array}{l}\text { 1. Adsorpt. } \times 1 \\
\text { 2. Ultrafilt. } \times 2 \\
\text { 3. Adsorpt. } \times 2 \\
\text { 4. Ultrafilt. } \times 3\end{array}$ & $\begin{array}{l}1.3 \\
.013 \\
.018 \\
.013\end{array}$ & \\
\hline 4 & $\begin{array}{l}\text { 1. Ultrafilt. } \times 3 \\
\text { 2. Adsorpt. } \times 1\end{array}$ & $\begin{array}{l}.036 \\
.022\end{array}$ & \\
\hline 5 & $\begin{array}{l}\text { 1. Adsorpt. } \times 1 \\
\text { 2. Ultrafilt. } \times 2 \\
\text { 3. Adsorpt. } \times 1\end{array}$ & $\begin{array}{l}5.3 \\
.016 \\
.016\end{array}$ & 1.15 \\
\hline 6 & $\begin{array}{l}\text { 1. Adsorpt. } \times 1 \\
\text { 2. Ultrafilt. } \times 3\end{array}$ & $\begin{array}{l}3.47 \\
.012\end{array}$ & 1.01 \\
\hline
\end{tabular}

* After each ultrafiltration, the product was ultracentrifuged. was possible to compare the mobility of hyaluronate, by hexuronic acid, and protein, by radioactivity. The first point to establish was that $\mathrm{I}^{131}$ labeled only the protein and not the hyaluronate. This was shown in the following experiments. $\mathrm{HP}$ was labeled with $\mathrm{I}^{131}$ and then digested with streptococcal hyaluronidase. A part of this sample was dialyzed and about 95 per cent of the hyalu-
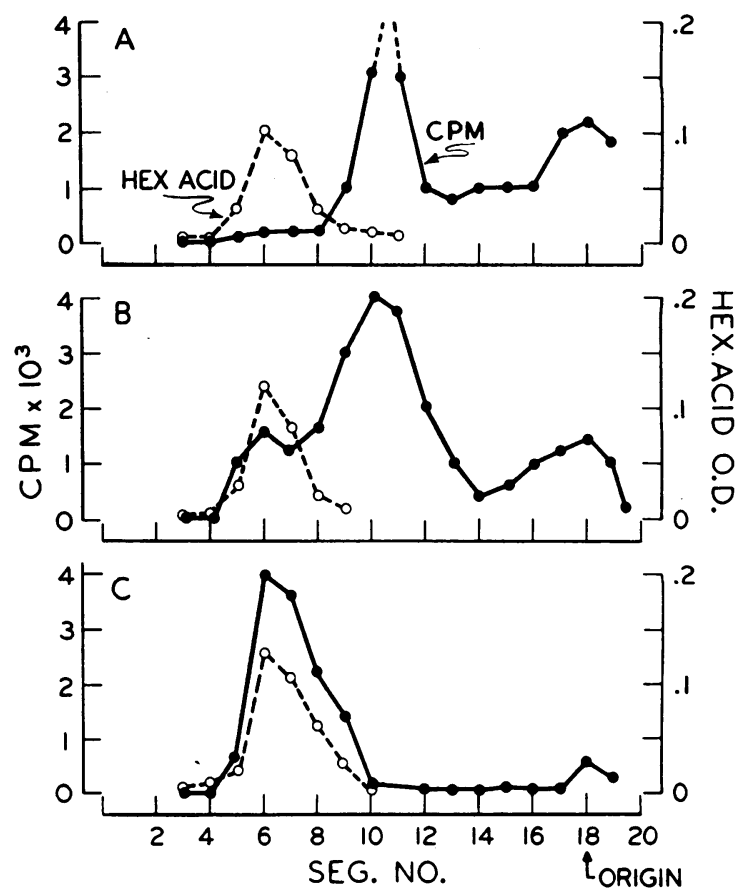

Fig. 1. Progressive purification of HP. Zone electrophoresis at $\mathrm{pH} 7.4$ on blocks of polyvinyl chloride of the following products obtained from synovial fluid: A, after 1 adsorption and 1 ultrafiltration, about 40 per cent protein; B, after 1 adsorption and 2 ultrafiltrations, 5 per cent protein; and C, final product (HP), after 1 adsorption and 4 ultrafiltrations, 2 per cent protein. The isolated products were labeled with $\mathrm{I}^{181}$ at different times, and the specific activities of the protein in A, B, C were different. 
TABLE III

Analyses of $H P^{*}$

\begin{tabular}{|c|c|c|c|c|c|c|c|c|c|c|}
\hline \multirow[b]{2}{*}{ Product } & \multirow[b]{2}{*}{$\begin{array}{c}\text { Hexuronic } \\
\text { acid }\end{array}$} & \multirow[b]{2}{*}{$\begin{array}{l}\text { Glucos- } \\
\text { amine }\end{array}$} & \multirow[b]{2}{*}{ Acetyl } & \multirow[b]{2}{*}{ Nitrogen } & \multirow[b]{2}{*}{ Proteint } & \multirow[b]{2}{*}{ Protein $\ddagger$} & \multirow[b]{2}{*}{ Ash (K) } & \multirow[b]{2}{*}{ Moisture } & \multicolumn{2}{|c|}{ Molar ratio } \\
\hline & & & & & & & & & $N / \mathrm{GM} \&$ & $\underset{\text { GM }}{\text { Hex. acid/ }}$ \\
\hline & $\%$ & $\%$ & $\%$ & $\%$ & $\%$ & $\%$ & $\%$ & $\%$ & & \\
\hline Theoretical \| & 44.60 & 41.15 & 13.79 & 3.22 & 0 & & 8.97 & 4.14 & 1.00 & 1.00 \\
\hline 1 & 34.82 & 31.91 & & 2.87 & 1.88 & 2.31 & 8.39 & 6.41 & 1.15 & 1.01 \\
\hline $2 a$ & 32.86 & 28.83 & & 2.61 & 1.75 & 2.25 & 8.16 & 1.82 & 1.16 & 1.05 \\
\hline 5 & 36.90 & 34.23 & & & 1.31 & 2.50 & & & 1.15 & 1.00 \\
\hline 6 & 39.30 & 34.94 & 17.55 & 2.77 & 1.28 & 0.25 & 2.60 & 6.76 & 1.01 & 1.04 \\
\hline
\end{tabular}

* After dialysis in KAc, HP was precipitated with 3 volumes of absolute alcohol, washed with ether, and dried in vacuum. Folin method using a $\gamma$ globulin standard. GM-glucosamine.

Calculated for $\mathrm{C}_{14} \mathrm{O}_{11} \mathrm{H}_{20} \mathrm{NK} \cdot \mathrm{H}_{2} \mathrm{O}$ (period weight 435) less 3 moles $\mathrm{H}_{2} \mathrm{O}$.

ronate fragments, but less than 3 per cent of the radioactivity, was recovered in the dialysate. The remainder of the digested $\mathrm{I}^{131}$-labeled sample was subjected to zone electrophoresis at $\mathrm{pH}$ 8.6. The hyaluronate fragments and the radioactivity appeared to be almost completely dissociated (see Figure 7,B).

To test whether some protein might be present

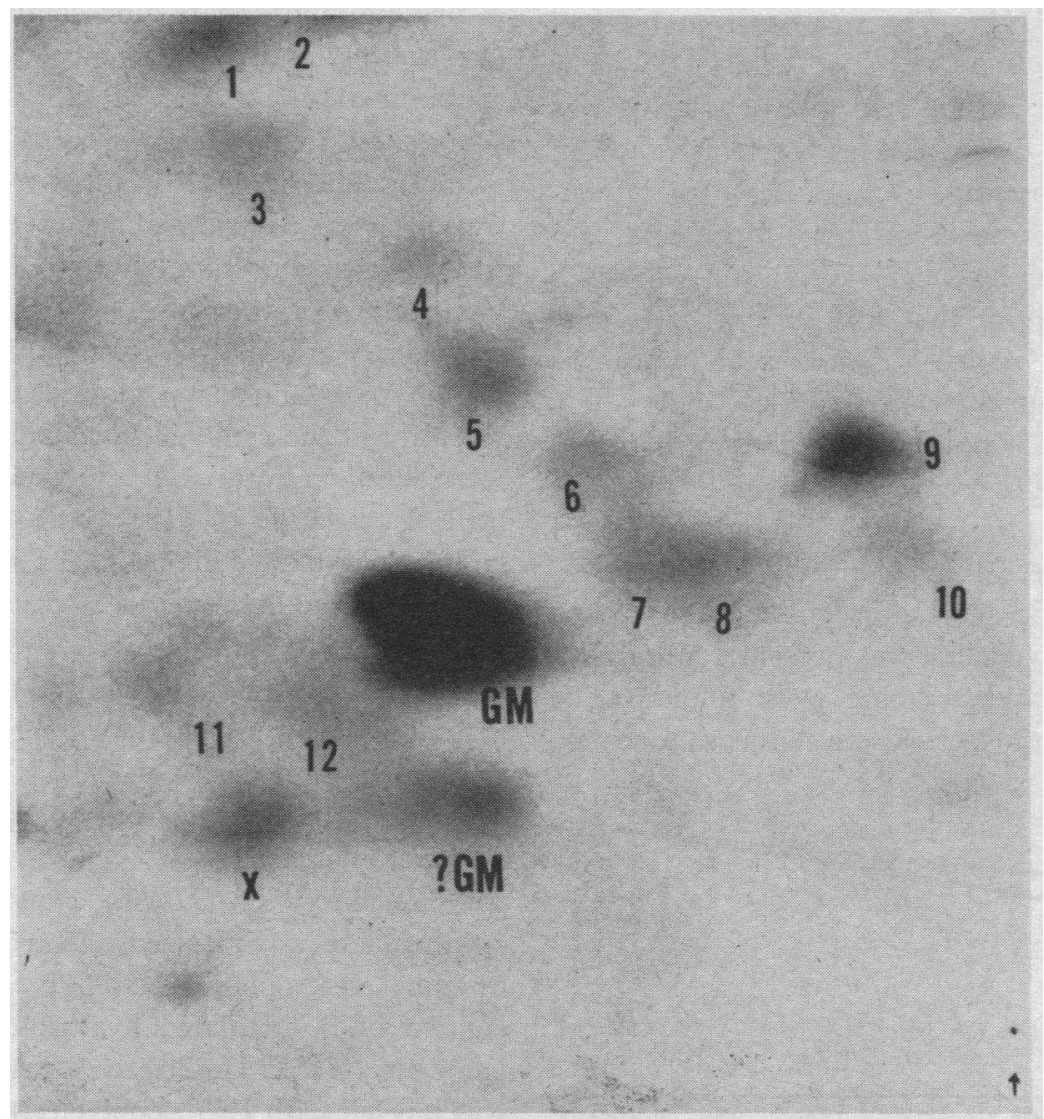

Fig. 2. ACID (6 N HCl) hydrolysis and two-dimensional chromatogRAPHY OF HP. 1, 2, 3-indantrione hydrate (Ninhydrin) spray. 1, leucineisoleucine; 2 , phenylalanine; 3 , valine; 4 , tyrosine; 5 , alanine; 6 , threonine; 7 , glycine; 8 , serine; 9 , glutamic acid; 10 , aspartic acid 11 , arginine; 12 , lysine; $\mathrm{X}$, unidentified; GM, glucosamine. 
in the isolated HP that $\mathrm{I}^{131}$ failed to label, a product was labeled with $\mathrm{Cr}^{51} \mathrm{Cl}$. Electrophoresis showed that almost 100 per cent of the radioactive material $\left(\mathrm{Cr}^{51}\right)$ migrated exactly with the hyaluronate toward the anode.

The progressive purification of HP during isolation from synovial fluid could be followed by zone electrophoresis of $\mathrm{I}^{131}$-labeled products (Figure 1). After adsorption on the column followed by one ultrafiltration, electrophoresis of a labeled product showed that 90 per cent of the radioactivity remained at the origin or migrated more slowly than hyaluronate (Tigure 1,A). With progressive purification of $\mathrm{HP}$, an increasing proportion of the total radioactivity migrated exactly with hyaluronate (Figure 1,B). In the final products, over 90 per cent of the radioactivity migrated with hyaluronate as a single peak toward the anode (Figure 1,C).

3. Analysis of $H P$. The results of analyses of several products are shown in Table III. The molar ratio of hexuronic acid to glucosamine was 1.00 to 1.04 . In three samples the molar ratio of nitrogen to glucosamine was 1.15 , which is consistent with the presence of about 2 per cent protein. In one sample (no. 6 ) this ratio was 1.01 , which would suggest that this product was protein-free; yet $\mathrm{I}^{131}$ labeled it, and acid hydrolysis and chromatography revealed amino acids.

The amino acids present in highest proportion in every product were serine, glycine, glutamic acid, and alanine (Figure 2). Smaller amounts of leucine, isoleucine, phenylalanine, valine, tyrosine, threonine, aspartic acid, and proline were identified. No hydroxyproline was present. Very faint traces of lysine and arginine were found. The only amino sugar observed was glucosamine; no

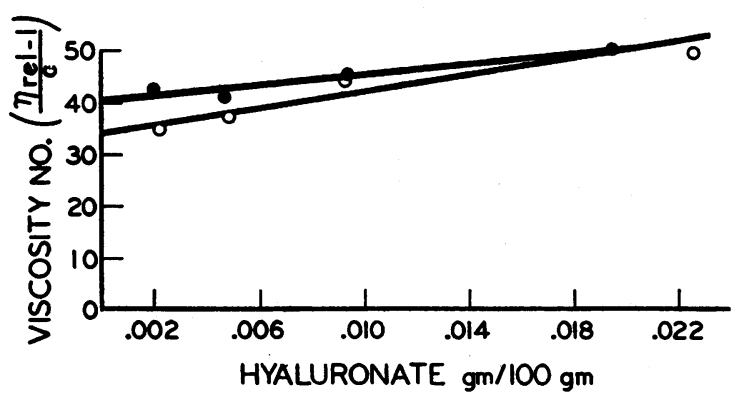

Fig. 3. Determination of intrinsic viscosity of STARTING SYNOVIAL FLUID (๑) AND HP ISOLATED FROM IT (O).

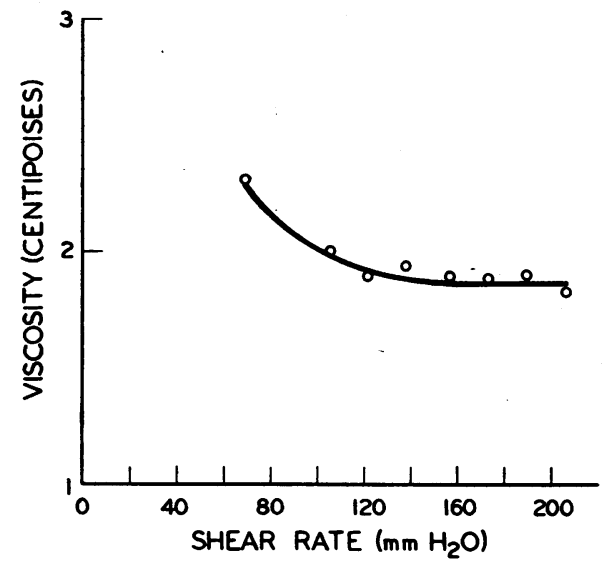

Fig. 4. Anomalous viscosity of HP.

neutral sugars were found. Many attempts to demonstrate hydrolysis products of nucleotides were unsuccessful, except on one occasion. Traces of uridine diphosphate glucosamine were found in one sample, and may have been due to bacterial contamination.

4. Viscosity. The viscosities of the starting synovial fluid and HP isolated from it by ultrafiltration were determined at several low concentrations of hyaluronate (.002 to $.02 \mathrm{~g}$ per cent) in viscometers of the same velocity gradient. Extrapolation of a plot of the results to zero concentration of hyaluronate showed that the intrinsic viscosity of the synovial fluid and the isolated HP were similar (Figure 3 ). This indicated that very little degradation of HP occurred during its isolation. Figures of about 36 for intrinsic viscosity are among the highest reported for isolated hyaluronate. HP from a subject 21 years of age and from one 79 years of age showed the same intrinsic viscosities. Figure 4 shows the non-Newtonian or anomalous viscosity of HP. The high viscosity at very low shear rates fell abruptly as the shear rate was increased.

5. Isolation of HP by zone electrophoresis. Hyaluronate was also isolated from synovial fluid by zone electrophoresis at $\mathrm{pH}$ 5.4. The protein content of this isolated hyaluronate was about 6 per cent (Table II, 2b). A part of this sample was labeled with $\mathrm{I}^{131}$. Zone electrophoresis of this labeled product at $\mathrm{pH} 8.6$ showed that over 50 per cent of the protein migrated more slowly than hyaluronate, either moving as $\gamma$ globulin or remaining at the origin. It was concluded that hy- 


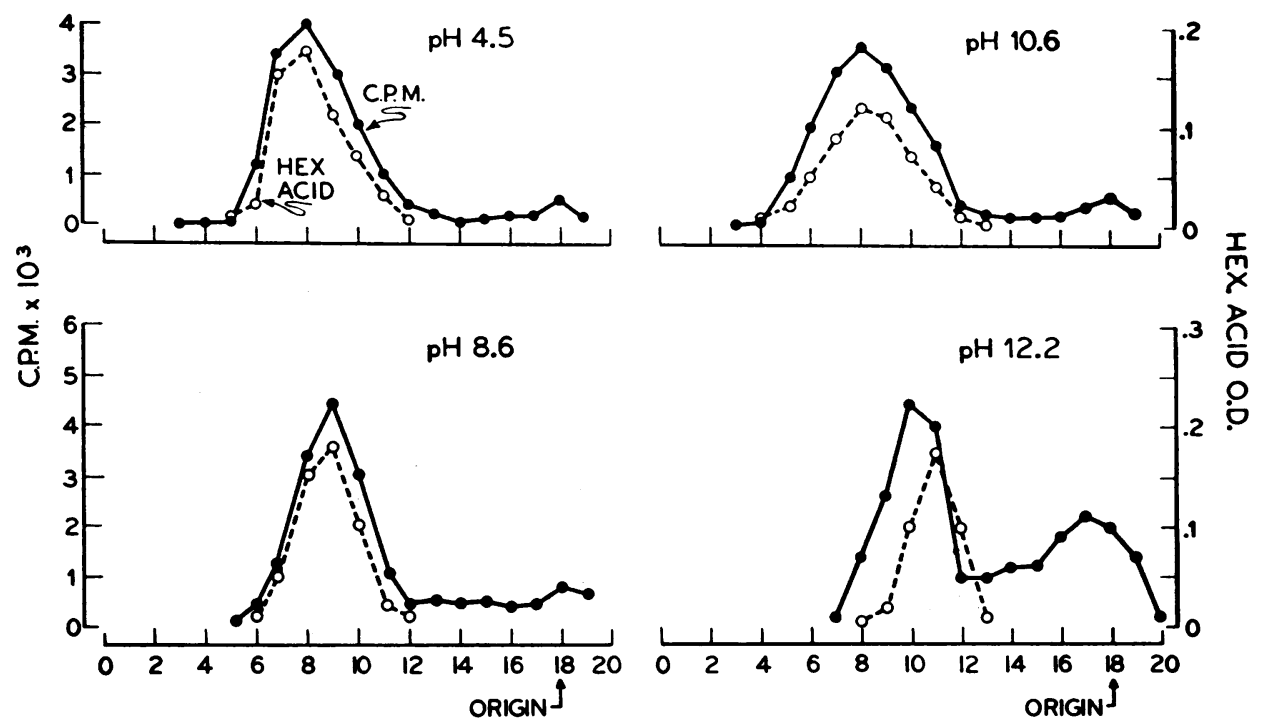

SEG. NO.

Fig. 5. Zone electrophoresis OVER a wide PH RANGe of I $^{131}$-LAbeled HP. A single peak is observed from $\mathrm{pH} 10.6$ to 4.5 ; at $\mathrm{pH} 12.2$ hyaluronate and protein are dissociated.

aluronate isolated by electrophoresis at $\mathrm{pH} 5.4$ contained some $\gamma$ globulin (9) which was bound to the hyaluronate by salt linkages and which was readily dissociated from hyaluronate by electrophoresis at $\mathrm{pH}$ 8.6. This extraneous protein was removed when the product isolated at $\mathrm{pH} 5.4$ was adsorbed with hydroxylapatite. The protein content of this adsorbed product was 1.5 per cent. It was labeled with $\mathrm{I}^{131}$, and zone electrophoresis at $\mathrm{pH} 7.4$ showed that over 90 per cent of the protein migrated exactly with hyaluronate. Like those products isolated by ultrafiltration and adsorption, the results of acid hydrolysis and paper chromatography of this product showed glucosamine, and predominantly serine, glycine, alanine, and glutamic acid.

6. Further evidence for a compound. a) Electrophoresis. $\mathrm{I}^{131}$-labeled HP migrated as a single peak toward the anode over a $\mathrm{pH}$ range from 11.2 to 3.5 (Figure 5). At $\mathrm{pH} 3.0$ the product failed to move from the origin. Dialysis at $\mathrm{pH} 2.5$ or 1.5 for 16 hours followed by zone electrophoresis at $\mathrm{pH} 4.5$ showed a single peak migrating toward the anode. At $\mathrm{pH} 12.5$ electrophoresis showed dissociation of hyaluronate and protein.

After electrophoresis at $\mathrm{pH} 7.4, \mathrm{I}^{131}$-labeled $\mathrm{HP}$ was isolated from the block. The specific activity of this product was determined, and it was then subjected to electrophoresis over a $\mathrm{pH}$ range of
11.1 to 4.5 . No change was found in the specific activity of the HP isolated after electrophoresis at each $\mathrm{pH}$.

High salt concentration $(0.3 \mathrm{M})$ or urea $(6 \mathrm{M})$ did not dissociate HP. To test whether added protein could dissociate HP, the following was done. Lysozyme, used because its net charge is positive at neutral $\mathrm{pH}(21)$, was labeled with $\mathrm{I}^{131}$ and added to unlabeled $\mathrm{HP}$ ( $1.5 \mu \mathrm{Eq}$ hyaluronate, $.03 \mu \mathrm{Eq}$ lysozyme $\left.\mathrm{I}^{131}\right)$. Zone electrophoresis at

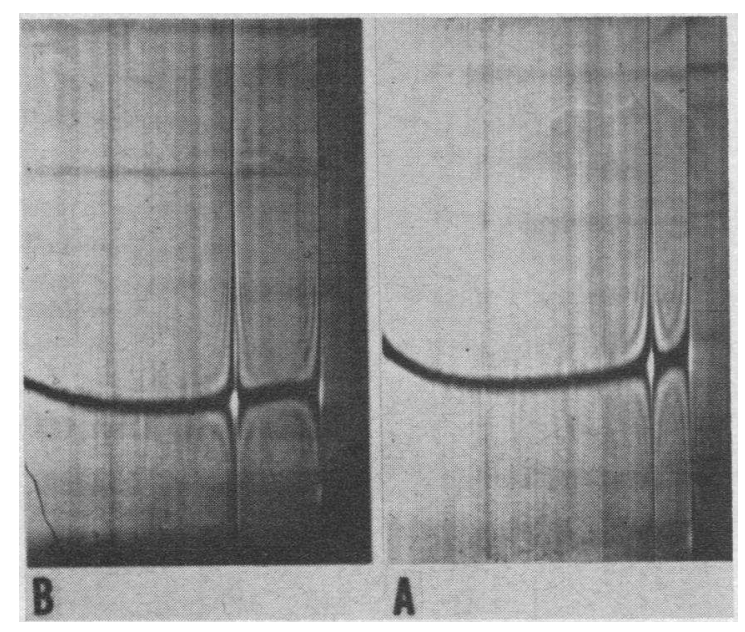

Fig. 6. Ultracentrifugation of HP. $1 \mathrm{mg}$ per $\mathrm{g}$ at 36 minutes (A) and 90 minutes (B) after reaching full speed, $59,780 \mathrm{rpm}$. Direction of sedimentation is from right to left. 
$\mathrm{pH} 7.4$ and 4.5 showed that lysozyme $\mathrm{I}^{131}$ migrated toward the cathode while HP moved toward the anode. In another experiment, lysozyme was added to $\mathrm{I}^{131}$-labeled HP. (0.3 $\mu \mathrm{Eq}$ of each). HP migrated as a single component and no protein, as marked by radioactivity, was displaced from HP by lysozyme.

b) Ultracentrifugation. HP was sedimented as a single component during ultracentrifugation (Figure 6). Schlieren diagrams revealed one sharp symmetrical peak. The sharpness of the peak is apparently due to the high molecular weight of $\mathrm{HP}$, and its symmetry suggests that $\mathrm{HP}$ is free of contamination.

c) Effects of digestion with bacterial hyaluronidases. HP was digested exhaustively with streptococcal and pneumococcal hyaluronidases, and then dialyzed. About 6 to 7 per cent of the total hexuronic acid remained in the nondialyzable residue. This finding suggests that part of the hyalu-

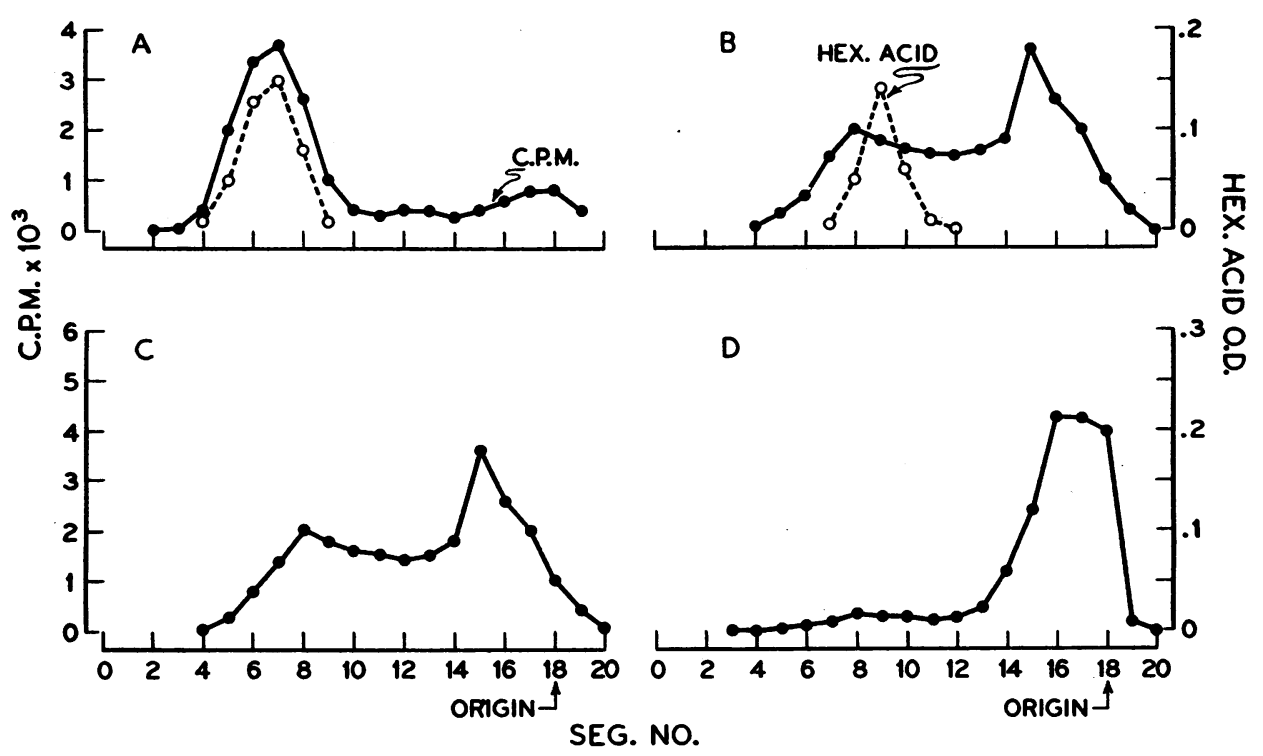

Fig. 7. Hyaluronidase and $\beta$-GLuCURonidase digestion of $I^{131}$-LABeled HP. Zone electrophoresis at $\mathrm{pH}$ 4.5. A, control. $\mathrm{B}$, digested with streptococcal hyaluronidase, but not dialyzed, to show position of hyaluronate fragments. C, after dialysis of B. D, further digestion of C with a liver enzyme containing $\beta$-glucuronidase and $\beta$-glucosaminidase. Note almost complete loss of component in $\mathrm{C}$ that moves toward the anode.

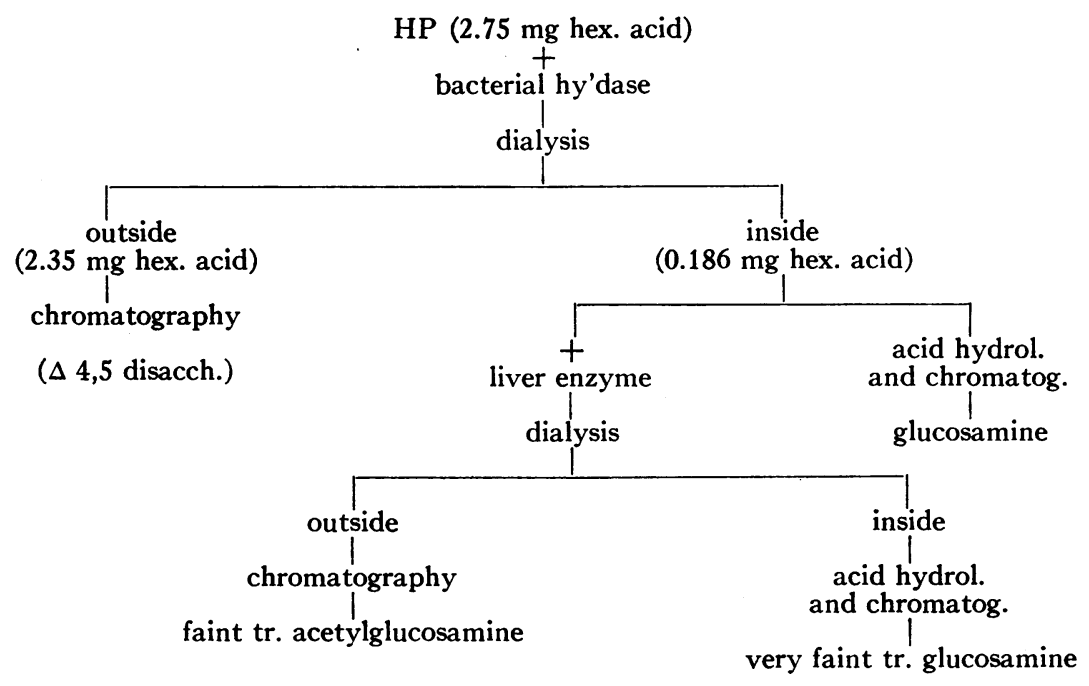


ronate is bound to protein through linkages resistant to digestion by hyaluronidase. Good evidence that the nondialyzable hexuronic acid was part of hyaluronate is shown in the following experiments, which are summarized here and in Figure 7.

Part of the nondialyzable residue that remained after hyaluronidase digestion was hydrolyzed in acid, and paper chromatography was carried out. The only amino sugar found was glucosamine. No galactosamine or neutral sugars were observed, indicating that no other anionic polysaccharide remained except hyaluronate residues. The remainder of the nondialyzable material was further digested with a liver enzyme containing $\beta$-glucuronidase and $\beta$-glucosaminidase, and dialyzed. Unfortunately, the presence of enzyme in both the dialysate and the nondialyzable material interfered with the colorimetric detection of hexuronic acid. It could be shown, however, that acetylglucosamine and hexuronic acid groups of hyaluronate in the nondialyzable residue were digested and rendered dialyzable by the liver enzyme. 1) Acetylglucosamine was detected in the dialysate by paper chromatography. 2) Electrophoresis at $\mathrm{pH} 4.5$ of an $\mathrm{I}^{131}$-labeled product digested with streptococcal hyaluronidase alone showed migration of about half the protein toward the anode (Figure 7,C), but after subsequent digestion with liver enzyme, almost all the protein remained immobile at the origin (Figure 7,D). This suggests removal by liver enzyme of hexuronic acid residues.

d) Effect of hydrazine. HP was treated with hydrazine under mild conditions that rupture ester bonds but avoid cleavage of peptide bonds. Free hydrazine was removed by dialysis, and bound hydrazides were measured by the intense yellow color formed after heating in the presence of $\mathrm{HCl}$ and $p$-dimethylaminobenzaldehyde. About 1.3 $\mu$ moles of bound hydrazide were formed per 1,000 $\mathrm{mg}$ of HP. Samples of HP not treated with hydrazine showed no color change after heating. The hydrazine-treated HP was digested with streptococcal hyaluronidase, and then dialyzed. The nondialyzable residue was tested for hexuronic acid, and about 8 per cent was found. A similar quantity of nondialyzable hexuronic acid had been found after streptococcal hyaluronidase digestion of HP without prior hydrazine treatment. This suggests that this nondialyzable hyaluronate residue is still bound to protein by bonds not susceptible to hydrazine treatment or streptococcal hyaluronidase digestion.

$\mathrm{I}^{131}$-labeled HP was also treated with hydrazine. Less than 10 per cent of the radioactivity was dialyzable. Zone electrophoresis at $\mathrm{pH} 4.5$ (Figure 8,C) showed at least two effects when compared to controls: 1) most of the protein had been split from HP and remained near the origin, and 2) a small part of the protein migrated rapidly toward the anode in the hyaluronate zone. This suggests that some protein may still be bound to hyaluronate by bonds resistant to hydrazine treatment.

e) Effect of reducing agents. Ascorbic acid or cysteine reduces by about one-third the relative viscosity of HP solutions. Zone electrophoresis
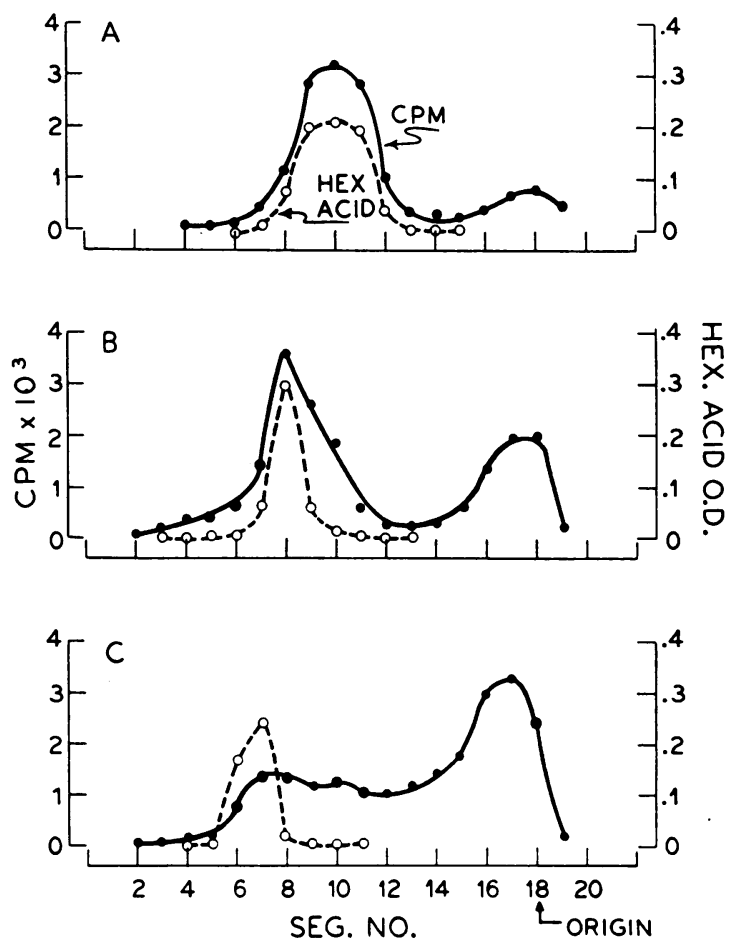

Fig. 8. Treatment of I ${ }^{131}$-LAbeled HP with hyDRAzINE. Zone electrophoresis at $\mathrm{pH}$ 4.5. A, control, untreated. $\mathrm{B}$, after incubation in barbital $(0.1 \mathrm{M}, \mathrm{pH}$ 8.6) 5 hours at $40^{\circ} \mathrm{C}$. HP moves as a single peak toward anode. Slight increase in protein at origin. $\mathrm{C}$, after treatment with hydrazine $(\mathrm{pH} 8.6) 5$ hours at $40^{\circ} \mathrm{C}$. Large amount of protein split from HP and remains near origin. Part of protein still in hyaluronate zone. 


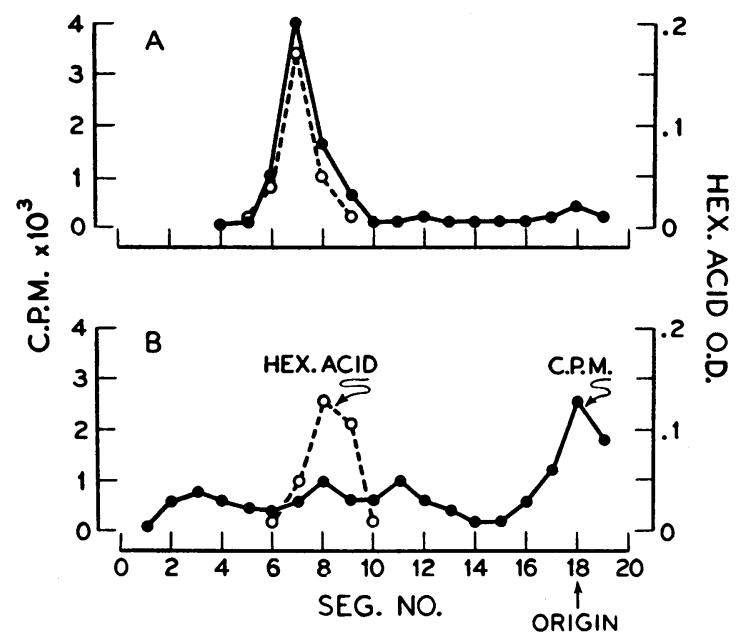

Fig. 9. EFFECt of PAPAIN on $\mathrm{I}^{131}$-Labeled HP. Zone electrophoresis at $\mathrm{pH}$ 8.6. A, control treated with cysteine $(0.04 \mathrm{M})$ alone. $\mathrm{B}$, treated with papain + cysteine.

of I ${ }^{131}$-labeled HP treated with either ascorbic acid or cysteine showed that HP migrated as a single peak toward the anode. If the protein were contained simply by mechanical entrapment within the domain of viscous hyaluronate, the lowering of hyaluronate's viscosity by reducing agents should have permitted the protein to be separated electrophoretically.

7. Effect of proteolytic enzymes. Either trypsin or papain, containing .04 M cysteine, caused proteolysis of the protein moiety of $\mathrm{HP}$. Papain digestion of $\mathrm{I}^{131}$-labeled HP caused about 40 per cent of the radioactivity, but no hyaluronate, to become dialyzable. Zone electrophoresis showed that the protein fragments split into several peaks, and most of these fragments migrated more slowly than hyaluronate (Figure 9,B). Neither

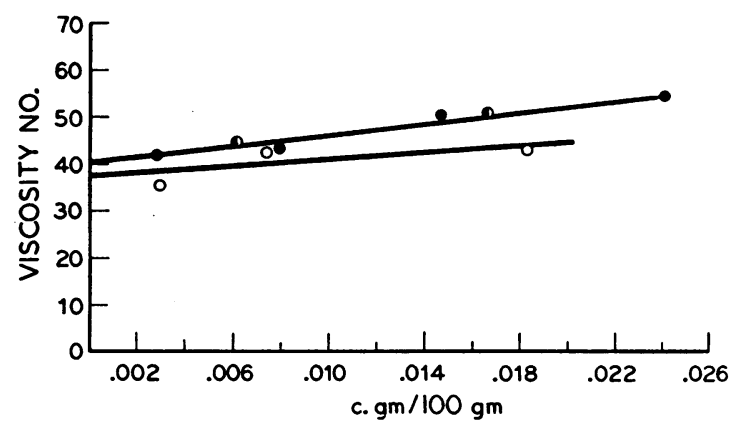

Fig. 10. EFfect of Proteolytic enzymes on IN-

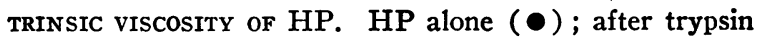
$(D)$; and after papain (O). trypsin nor papain appreciably lowered the intrinsic viscosity of HP (Figure 10).

\section{DISCUSSION}

This paper describes mild methods to isolate hyaluronate from large volumes of pooled normal human synovial fluid. Hyaluronate containing about 2 per cent protein was isolated by a combination of adsorption, ultrafiltration, and ultracentrifugation. This product was called hyaluronateprotein (HP). These isolation procedures were sufficiently mild so that the final product had an intrinsic viscosity similar to the starting synovial fluid, and possessed anomalous viscosity.

Hyaluronate can be separated from the bulk of the proteins of synovial fluid by a number of mild methods, such as electrophoresis, ultrafiltration, and precipitation with cetylpyridinium chloride, but additional procedures are always necessary to remove traces of contaminating protein (22). Proteolytic enzymes, such as pepsin, papain, pancreatic and intestinal extracts, and trypsin, have been used for this purpose. At least two of these enzymes, papain and trypsin, have been shown in the present study to remove most of the small quantity of protein firmly bound to hyaluronate. Contaminating protein has been removed by inert adsorbents such as Lloyd's reagent, Celite, and charcoal-cellulose mixtures, and by ultracentrifugation. By a combination of electrodeposition, adsorption, and ultracentrifugation, there have been isolated from synovial fluids some products apparently free of protein, since their molar ratios of nitrogen to glucosamine were $1.00(3,4)$. As this paper shows, however, the very small quantity of protein firmly bound to hyaluronate may not be detected by analyses for nitrogen and glucosamine. In the present study, protein was detected by showing the presence of amino acids, by labeling the protein with ${ }^{-}{ }^{131}$, and by demonstrating proteolysis after digestion with trypsin or papain. It was then necessary to show that hyaluronate and protein were combined. Perhaps the most suitable method, and one that appears not to have been previously applied for this purpose, is the iodination of the protein moiety and determination of the electrophoretic behavior of the labeled product. The evidence presented in this paper that HP is a compound may be summarized as follows. 
1. Repeated attempts to remove additional protein by adsorption of $\mathrm{HP}$ - with Celite, carboxymethyl cellulose, or IRC-50 and hydroxylapatitefailed to lower the protein content.

2. Products isolated after multiple ultrafiltrations and adsorptions showed similar analyses.

3. A product obtained by an entirely independent method, zone electrophoresis at $\mathrm{pH} 5.4$ and adsorption, showed a similar protein content and similar amino acid composition to $\mathrm{HP}$ isolated by ultrafiltration.

4. Acid hydrolysis and paper chromatography of each isolated product showed the same amino acids in high proportion: alanine, serine, glycine, and glutamic acid.

5. The $I^{131}$-labeled protein and hyaluronate migrated as a single peak over a $\mathrm{pH}$ range of 11.2 to 3.5. $\mathrm{HP}$ was not dissociated by low $\mathrm{pH}(1.5)$, high salt concentration $(0.3 \mathrm{M})$, or urea $(6 \mathrm{M})$. Cysteine or ascorbic acid, which markedly reduced the viscosity of HP, did not dissociate it. Nor did lysozyme, a protein with a net cationic charge at neutral $\mathrm{pH}$, dissociate $\mathrm{HP}$ or displace the protein moiety of HP.

6. After exhaustive digestion of HP with bacterial hyaluronidase and dialysis, there remained a nondialyzable fraction containing all the protein and 6 to 7 per cent of the hyaluronate. This is good evidence that hyaluronate is bound to protein by chemical bonds not susceptible to bacterial hyaluronidase digestion. Further digestion of the nondialyzable residue with a liver enzyme containing $\beta$-glucuronidase and $\beta$-glucosaminidase removed hexuronic acid and acetylglucosamine groups of hyaluronate.

Dissociation of $\mathrm{HP}$ at $\mathrm{pH} 12.5$ suggested that hyaluronate and protein might be combined by ester linkages. To study this possibility, HP was treated with hydrazine. This reagent has been used to demonstrate "ester-like" linkages in collagen (23). Under the mild conditions employed in the present study, ester bonds should be cleaved with formation of hydrazides at the $\mathrm{COO}^{-}$position where the ester was previously present. Alternatively, a hydrazone might be formed at the reducing end of the hyaluronate. It was found that $1.3 \mu$ moles of bound hydrazide or hydrazone were formed per $1000 \mathrm{mg}$ of HP. Expressed as moles, 1.3 moles of bound hydrazide or hydrazone were formed per $10^{6} \mathrm{~g}$ of HP. This result is com- patible with formation of a hydrazone, assuming the molecular weight of hyaluronate to be $10^{6}$. On the other hand, there is the possibility, based on the results of electrophoresis of hydrazinetreated, $\mathrm{I}^{131}$-labeled $\mathrm{HP}$, and on the probability that the molecular weight of hyaluronate exceeds $10^{6}(4)$, that ester bonds might have been broken and a hydrazide formed. In an attempt to resolve this question, hydrazine-treated HP was digested with streptococcal hyaluronidase and dialyzed. Bound hydrazides were found in both the dialysate and the nondialyzable fractions, suggesting that ester bonds were split, but the results must still be considered tentative because of color imparted to the solutions by the enzyme. If hydrazine treatment broke ester bonds, such bonds might be formed 1) through $\mathrm{COO}^{-}$groups of hyaluronate and $\mathrm{OH}$ groups of serine or threonine, 2) through $\mathrm{COO}^{-}$groups of dicarboxylic amino acids and $\mathrm{OH}$ groups of hyaluronate, or 3) through terminal $\mathrm{COO}^{-}$groups of an amino acid and $\mathrm{OH}$ groups of hyaluronate; an example of this type of bond in a proteinpolysaccharide is found in teichoic acids where terminal $\mathrm{COO}^{-}$groups of alanine residues are linked to $\mathrm{OH}$ groups (either glucosyl or ribitol) of the polymer (24). In addition to these three possibilities, inter-chain ester links could be present in either hyaluronate or protein.

Assuming that hydrazine-treatment of HP led to rupture of ester bonds rather than hydrazone formation, a preliminary picture may be proposed for the structure of HP (Table IV). This scheme is based chiefly on: 1) the finding of 6 to 7 per cent of nondialyzable hyaluronate after digestion of HP, or of hydrazine-treated HP, with streptococcal hyaluronidase ; 2) the failure of proteolytic enzymes to reduce the intrinsic viscosity of $\mathrm{HP}$; and 3) the electrophoretic pattern observed after hydrazine-treatment of $\mathrm{I}^{131}$-labeled HP (Figure $8, \mathrm{C})$.

Comparison of $\mathrm{HP}$ with the more widely studied chondromucoprotein (CMP) isolated chiefly from bovine nasal cartilage is relevant (Table IV). Unlike HP, preparations of CMP contain about 25 per cent protein firmly bound to chondroitin sulfate (25-28). Like HP, the protein of CMP contains a high proportion of dicarboxylic amino acids and serine, and Muir (25) suggested that serine of the protein might be combined in esterlinkage with part of the "acidic groups" of chon- 
Comparisons of HP and chondramucoprotein (CAP) from cartilage.

\begin{tabular}{|c|c|c|c|}
\hline & $\underline{\mathrm{IP}}$ & $\underline{\text { GPP }}$ & Reference \\
\hline \% protein & 2 & About 25 & $(25-28)$ \\
\hline Intrinsic viscosity & 35 & $2.7-4.5$ & $(26,27)$ \\
\hline $\begin{array}{l}\text { Viscosity after } \\
\text { protoolytic enz. }\end{array}$ & $\begin{array}{l}\text { Little } \\
\text { change }\end{array}$ & $\begin{array}{l}\text { Marked } \\
\text { fall }\end{array}$ & (25) \\
\hline Effect of alkali & Dissociation & Dissociation & $(25,26,29)$ \\
\hline $\begin{array}{l}\text { Other anionic } \\
\text { polysacc. }\end{array}$ & $\begin{array}{l}\text { None } \\
\text { found }\end{array}$ & ? Keratosulfate & (28) \\
\hline $\begin{array}{l}\text { Major amino acids } \\
\text { in protein }\end{array}$ & $\begin{array}{l}\text { Dicarboxylic; serine; } \\
\text { glycine; alanine }\end{array}$ & Same & $(25,27)$ \\
\hline Ultracentrifugation & I component & 2 components & (26) \\
\hline
\end{tabular}
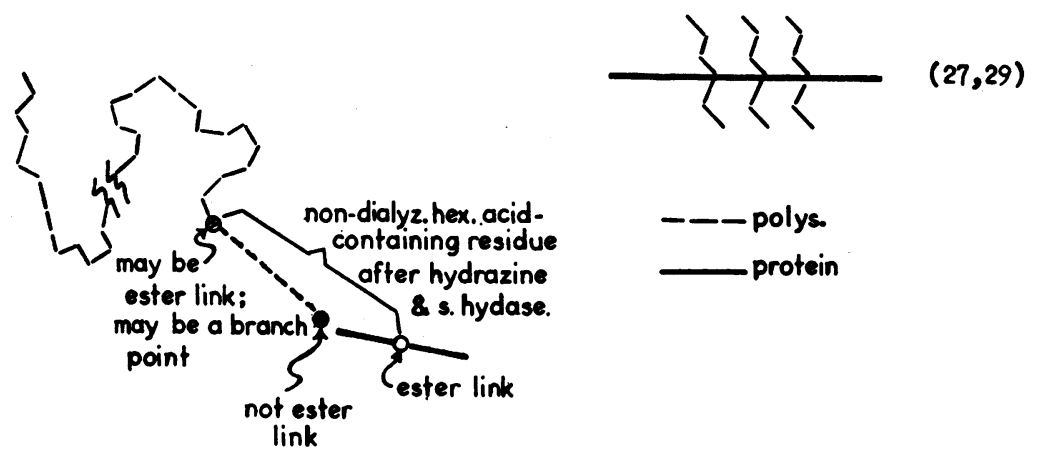

droitin sulfate. The links between protein and chondroitin sulfate are disrupted by prolonged incubation in alkali $(26,29)$. The effects of proteolytic enzymes point out major differences in the structure of CMP and HP. The moderately high viscosity of solutions of CMP is markedly reduced after digestion with trypsin or papain, and the molecular weight falls from $10^{6}$ or more to less than 50,000 . This finding has led to suggestions that many chondroitin sulfate units of short chain length are bound to a long protein core. Hyaluronate chains are probably much longer and occupy a domain that is even larger than their actual size (30). Interpenetration or overlap of these highly solvated molecules, even at low concentration, accounts for the extremely high viscosity and shear-dependent viscosity of hyaluronate solutions. Digestion of $\mathrm{HP}$ with proteolytic enzymes does not reduce appreciably the intrinsic viscosity or the anomalous viscosity (6) of hyaluronate solutions. This suggests that hyaluronate exists as an uninterrupted long-chain polymer with protein present as side chains, or at the end(s) of the hyaluronate molecule, or both.

The biological role of the small amount of protein firmly bound to the hyaluronate is not known. The protein may play some role, not yet defined, in the physical properties of the hyaluronate molecule; it may participate in the synthesis of hyaluronate in synovial membrane cells, or protein may be added to the hyaluronate at the cell wall, and play a role in the passage of hyaluronate into the synovial fluid.

\section{SUM MARY}

1. From normal human synovial fluids, hyaluronate consistently containing about 2 per cent protein was isolated by a combination of ultrafiltration and adsorption. A similar product was 
obtained from synovial fluids by zone electrophoresis at $\mathrm{pH} 5.4$ and adsorption. Evidence that hyaluronate and protein were firmly combined led to use of the term hyaluronateprotein (HP) to describe this product.

2. HP was labeled with $\mathrm{I}^{131}$, and zone electrophoresis over a $\mathrm{pH}$ range of 11.2 to 3.5 showed migration of hyaluronate, measured as hexuronic acid, and protein, measured by radioactivity, as a single peak toward the anode. Neither high salt concentration, urea, nor addition of a basic protein dissociated hyaluronate and protein.

3. After exhaustive digestion of HP with bacterial hyaluronidase and dialysis, there remained about 6 to 7 per cent nondialyzable hyaluronate bound to all the protein. This is good evidence that hyaluronate is bound to protein by chemical bonds not susceptible to bacterial hyaluronidase digestion. Further digestion of the nondialyzable residue with a liver enzyme containing $\beta$-glucuronidase and $\beta$-glucosaminidase removed hexuronic acid and acetylglucosamine groups of hyaluronate.

4. Treatment of HP with hydrazine led to formation of $1.3 \mu$ moles of nondialyzable hydrazide or hydrazone per $1000 \mathrm{mg}$ of HP. Some evidence suggests that ester bonds were split and a hydrazide formed.

5. A preliminary scheme for the structure of $\mathrm{HP}$ is proposed.

\section{ACKNOWLEDGMENT}

We wish to thank Drs. Paul Gallop and Olga Blumenfeld for helpful discussions concerning the use of hydrazine.

\section{ADDENDUM}

The free aldehyde group of HP was reduced with $\mathrm{NaBH}_{4}$, and the product then treated with hydrazine. The same amount of bound hydrazide was formed as in control samples not reduced with $\mathrm{NaBH}_{4}$, indicating that hydrazides were formed and not a hydrazone.

\section{REFERENCES}

1. Hamerman, D., and Schuster, $H$. Hyaluronate in normal human synovial fluid. J. clin. Invest. 1958, $37,57$.

2. Schmid, K., and MacNair, M. B. Characterization of the proteins of certain post-mortem human synovial fluids. J. clin. Invest. 1958, 37, 708.

3. Balazs, E. A., and Sundblad, L. Viscosity of hyaluronic acid solutions containing proteins. Acta Soc. Med. upsalien. 1959, 64, 137.
4. Balazs, E. A., Watson, D., Duff, I. F., and Roseman, S. Report on the molecular parameters of hyaluronic acid from human synovial fluid. Personal communication from E. A. Balazs.

5. Ogston, A. G., and Stanier, J. E. Further observations on the preparation and composition of the hyaluronic acid complex of ox synovial fluid. Biochem. J. 1952, 52, 149.

6. Ogston, A. G., and Sherman, T. F. Degradation of the hyaluronic acid complex of synovial fluid by proteolytic enzymes and by ethylenediaminetetraacetic acid. Biochem. J. 1959, 72, 301.

7. Schubert, M. Nomenclature of polysaccharides. Arth. Rheum. 1961, 4, 218.

8. Tiselius, A., Hjertén, S., and Levin, Ö. Protein chromatography on calcium phosphate columns. Arch. Biochem. 1956, 65, 132.

9. Hamerman, D., and Sandson, J. Isolation of hyaluronate from synovial fluid by zone electrophoresis. Nature (Lond.) 1960, 188, 1194.

10. Pressman, D., and Eisen, H. N. The zone of localization of antibodies. V. An attempt to saturate antibody-binding sites in mouse kidney. J. Immunol. 1950, 64, 273.

11. Smith, I. Chromatographic Techniques. New York, Interscience, 1958.

12. Block, R. J., Durrum, E. L., and Zweig, G. A Manual of Paper Chromatography and Paper Electrophoresis, 2nd ed. New York, Academic Press, 1958.

13. Salton, M. R. J. An improved method for the detection of $\mathrm{N}$-acetylamino sugars on paper chromatograms. Biochim. biophys. Acta 1959, 34, 308.

14. Levine, M. G., and Kling, D. H. Rheological studies on synovial fluid. J. clin. Invest. 1956, 35, 1419.

15. Barnett, C. H. Measurement and interpretataion of synovial fluid viscosities. Ann. rheum. Dis. 1958, 17, 229.

16. Meyer, $\mathrm{K}$. The chemistry of the mesodermal ground substances. Harvey Lectures 1957, series 51, 88.

17. Seifter, S., Gallop, P. M., Michaels, S., and Meilman, E. Analysis of hydroxamic acids and hydrazides; preparation and properties of dinitrophenyl derivatives of hydroxamic acids, oximes, hydrazides, and hydrazones. J. biol. Chem. 1960, 235, 2613.

18. Lowry, O. H., Rosebrough, N. J., Farr, A. L., and Randall, R. J. Protein measurement with the folin phenol reagent. J. biol. Chem. 1951, 193, 265.

19. Dische, Z. A new specific color reaction of hexuronic acids. J. biol. Chem. 1947, 167, 189.

20. Bowness, J. M. Application of the carbazole reaction to the estimation of glucuronic acid and glucose in some acidic polysaccharides and in urine. Biochem. J. 1957, 67, 295.

21. Schubert, M., and Franklin, E. C. Interaction in solution of lysozyme with chondroitin sulfate and its parent proteinpolysaccharide. J. Amer. chem. Soc. 1961, 83, 2920. 
22. Balazs, E. A. Physical chemistry of hyaluronic acid. Fed. Proc. 1958, 17, 1086.

23. Gallop, P. M., Seifter, S., and Meilman, E. Occurrence of "ester-like" linkages in collagen. Nature (Lond.) 1959, 183, 1659.

24. Armstrong, J. J., Baddiley, J., and Buchanan, J. G. Structure of the ribitol teichoic acid from the walls of Bacillus subtilis. Biochem. J. 1960, 76, 610.

25. Muir, $H$. The nature of the link between protein and carbohydrate of a chondroitin sulfate complex from hyaline cartilage. Biochem. J. 1958, 69, 195.

26. Gerber, B. R., Franklin, E. C., and Schubert, M. Ultracentrifugal fractionation of bovine nasal chondromucoprotein. J. biol. Chem. 1960, 235, 2870.
27. Mathews, M. B., and Lozaityte, I. Sodium chondroitin sulfate-protein complexes of cartilage. I. Molecular weight and shape. Arch. Biochem. 1958, 74, 158.

28. Partridge, S. M., Davis, H. F., and Adair, G. S. The chemistry of connective tissues. 6. The constitution of the chondroitin sulfate-protein complex in cartilage. Biochem. J. 1961, 79, 15.

29. Partridge, S. M., and Elsden, D. F. The chemistry of connective tissues. 7. Dissociation of the chondroitin sulfate-protein complex of cartilage with alkali. Biochem. J. 1961, 79, 26.

30. Ogston, A. G., and Phelps, C. F. The partition of solutes between buffer solutions and solutions containing hyaluronic acid. Biochem. J. 1961, 78, 827.

\section{SPECIAL NOTICE TO SUBSCRIBERS}

Post Offices will no longer forward the Journal when you move.

Please notify The Journal of Clinical Investigation, Business Office, 10 Stoughton Street, Boston 18, Mass., at once when you have a change of address, and do not omit the zone number if there is one. 